\title{
Drought, water scarcity and UK businesses and industries. An exploratory study into challenges and opportunities*
}

Kevin Grecksch ${ }^{1 *}$, Zita Stefán ${ }^{2}$

${ }^{1}$ Centre for Socio-Legal Studies, Manor Road Building, Manor Road, Oxford, OX1 3UY, United Kingdom; kevin.grecksch@csls.ox.ac.uk

${ }^{2}$ Centre for Socio-Legal Studies, Manor Road Building, Manor Road, Oxford, OX1 3UY, United Kingdom; zitastefan91@gmail.com

*Corresponding author

\begin{abstract}
In water resources management and drought and water scarcity management specifically, large business and industrial abstractors are a neglected stakeholder group. Yet, supply chains and production processes often rely on continuous water supply. Droughts and water scarcity can therefore have an adverse effect on businesses and industry. This exploratory study focusses on the UK, where droughts are a recurring feature of the climate, and three business sectors horticulture, food and drink and the Scotch whisky industry. The analysis of interviews with trade bodies from the three sectors is complemented by relevant literature and documents. The findings show that the role of drought within each sector differs, how important relationships with other business and industry sectors are, as well as the importance of good relationships with regulatory bodies and water companies. The results highlight that proactive measures such as new water saving technologies or water recycling, are of equal importance.
\end{abstract}

\section{Keywords}

UK, drought; water scarcity; business; industry; water management

\section{Acknowledgments}

This work was supported by the John Fell Oxford University Press (OUP) Research Fund 


\section{Introduction}

This research seeks to shed light on a new and underexplored issue in water resource management: how large UK water consumers prepare for water shortages, which are becoming increasingly frequent as part of a changing UK climate (Committee on Climate Change Risk Assessment, 2016; Marsh et al., 2007). The most recent drought event in the UK took place between 2010 and 2012 (Met Office, 2013). Drought, although difficult to define precisely (Lloyd-Hughes, 2013; Wilhite et al., 2014), is here defined as deficit of water relative to normal conditions (Lloyd-Hughes, 2013). Water scarcity is defined as the result of long-term unsustainable use of water resources, which water managers can influence (Van Loon and Van Lanen, 2013). Factors that further exacerbate the UK's risk for droughts are climatic changes, population growth and changing water demand patterns. Climate change will intensify the competition for water among agriculture, ecosystems, settlements, industry and energy production, affecting region water, energy and food security (Bates et al., 2008; Jiménez Cisneros et al., 2014).

While potential impacts of climate change on organisations are discussed in literature (Gasbarro et al., 2016; Linnenluecke et al., 2012; Weinhofer and Busch, 2013; Winn et al., 2011), industrial or large business water abstractors, however, are often less discussed in academic research and policy debates, which are focused on domestic consumption of water (Brown and Hess, 2017; Hoolohan and Browne, 2016; Nauges and Wheeler, 2017) or primarily focussed on the agricultural sector (Rey et al., 2016). Lange \& Cook (2015) map and discuss the drought governance space for managing drought in the UK and among other important issues name the key actors in the drought governance space. We find the regulatory bodies, water companies, water consultancies, the economic regulator for the water companies (Ofwat), but business and industrial abstractors do not belong to it (Lange and Cook, 2015).

Yet, water is used by businesses and industry either directly for manufacturing products or for washing, cooling or heating during production processes. As early as the 1950s rising water demands by UK industry became an issue. Water was used in expanding electricity, nuclear 
power, steel, chemical and paper industries (Taylor et al., 2009). The 1959 drought highlighted the needs of industries: "In September 1959, representatives of the heavy and chemical industries of Teesside, reduced to half supply, met with the Tees Valley and Cleveland Water Board, pointing out that this kind of production 'can't just be switched on and off suddenly'. The drought was estimated to have cost Teesside firms around £100,000” (Taylor et al., 2009). During the 1976 drought, the emphasis was on protecting national industry (Morren, 1980).

Hence, businesses and industries need water in order to maintain supply chains and production lines, yet water consumers are discussed in a general sense with limited distinction between the public and private sectors, and the different types of large private industrial abstractors who have different needs and organisational histories in dealing with water. According to the latest report by the UK's Committee on Climate Change: "some water intensive industries are clustered in areas at risk of water scarcity such as paper manufacturing in Kent and chemicals manufacturing in the northwest of England." (Committee on Climate Change Risk Assessment, 2016) The impact of flooding is usually more visible not least supported by the media (BBC News, 2016), yet the effects and consequences such as interrupted supply chains potentially are the same for droughts and water scarcity. Upholding supply chains and production processes is not only necessary from a wider economic point of view but especially interruptions to food and drink supply chains can have knock-on effects such as empty supermarket shelves or increased prices for groceries. Industries and businesses should therefore have an intrinsic interest in proactive drought and water scarcity management in order to avoid the potential consequences.

In Spain, the losses of the 2007-2008 drought were significant. Apart from agriculture, sectors such as horticulture, hydropower production and non-market welfare losses like environmental damage (river basin ecosystems) all suffered from the consequences of water scarcity. "The total costs of the extreme drought event affecting the metropolitan area of Barcelona in 2007 and 2008 have been estimated here at 1,605 million Euros”. (Martin-Ortega et al., 2012) Jenkins (2013) emphasises the indirect losses of drought, for example mining, retail, finance and insurance, educational services, healthcare, arts, entertainment, recreation or 
accommodation and food services. Linnenluecke et al. (2012) point out with reference to the 2010 Russian drought and wildfires that although companies in the affected areas have significant adaptive capabilities for competitive environments, they were unable to assemble or did not possess suitable resources and capabilities for withstanding and recovering from impacts.

For the UK, Benton et al. (2012) highlight the sensitivity of the UK food supply chain: "The UK food chain is inherently resilient due to the diversity of suppliers, retailers and sources of imported food. However, the just-in-time nature of the UK food chain does mean that severe weather may cause significant disruption, albeit this likely to be over a timescale of days, or at most a week or two in the case of severe weather." More specifically for a certain sector, Thomas (2015) points out: "Clearly, climate change is going to affect barley quality as well as yield, which will in turn affect the efficiency of major end-users such as maltsters, brewers and distillers."

This research aims to answer the question what role drought and water scarcity have among UK industries and businesses and whether these industries and businesses have strategies and plans to first of all react to drought and water scarcity and second if they already apply any proactive measures to prevent potential disruptions from drought and water scarcity. Furthermore, this research tries to elicit the relationship businesses and industries have to the regulatory bodies and water companies. The research focusses not on individual companies but rather tries to explore a general picture based on policies and strategies by trade associations. In addition, the paper presents three sectors, food and drink, horticulture and the Scottish Whisky industry, in detail. The paper therefore contributes to the rich debate about water governance, water resources management and discussions about the so-called water-energyfood nexus (WEF-nexus) (Green et al., 2017).

\section{Materials and Methods}

The data presented in this research rests on two sources, a literature and document review and a small number of exploratory semi-structured expert interviews. The aim of the literature and 
document review was to provide an overview over current ideas, strategies and policies regarding large water abstractors and drought and water scarcity. The review included academic literature and documents from UK trade associations that could be affected heavily by drought and water scarcity. This included the paper industry, food and drink industry, Scottish whisky industry, the horticultural trade, the British glass industry and the British hydropower industry. The websites of these trade organisations were searched for documents, policies or statements with regard to drought and water scarcity. The review of academic literature focussed on the UK and the European Union. Academic literature was searched using ScienceDirect, Scopus and Web of Science search engines. Articles were selected on the basis that they deal with industries or businesses and drought and water scarcity and a snowball search using cross-references.

In the next step, representatives of all mentioned trade associations were contacted via email or telephone and interviews requested. Only three trade associations responded positively and interviews were conducted with the Horticultural Trade Association (HTA), the Food and Drink Federation (FDF) and the Scotch Whisky Association (SWA) (Table 1). Others did either not respond or declined the interview request. Those who declined mentioned that the issue is not seen as relevant among their membership. The semi-structured interviews lasted one hour and were conducted based on methods of the focused, problem centred and expert interview (Fowler and Mangione, 1990; Merton and Kendall, 1946; Witzel, 2000). The collected literature and documents and transcribed interviews were analysed based on the method of qualitative content analysis (Bryman, 2012; Mayring, 2008).

Table 1. List of interviews

\begin{tabular}{|l|l|}
\hline Interview name & Interviewee \\
\hline Interview HTA & John Adlam (Horticultural Trade Association) \\
\hline Interview FDF & David Bellamy (Food and Drink Federation) \\
\hline
\end{tabular}




\begin{tabular}{|l|l|}
\hline Interview SWA & $\begin{array}{l}\text { both interviewees anonymised (representative from } \\
\text { trade association and representative from whisky } \\
\text { distillery) }\end{array}$ \\
\hline
\end{tabular}

In order to answer the research question the following categories were used to analyse the data. First, the role of drought and water scarcity within trade organisations was assessed. This tried to elicit the importance of the issue and whether it is competing against other water related issues such as flooding or wastewater recycling or any non-water related issues.

Second, the analysis assessed in how far trade associations' membership businesses could be affected by drought and water scarcity and whether this is reflected in any strategies, policies or reports. The interruption of supply chains, the availability of water for production processes are just two of the potential consequences of drought and water scarcity and this category tries to establish in how far trade associations are aware of possible affects.

A further category assessed the nature and extent of the relationship between trade associations and regulatory bodies such as the UK Department for the Environment, Food and Rural Affairs (DEFRA), the Environment Agency (EA), the Scottish Environment Protection Agency (SEPA) and UK water companies. These actors represent the key actors in the UK drought governance space [10]. Hence, relationships with them are vital for effective drought and water scarcity management.

A fourth category elicited the experience with previous drought events and whether this resulted in any changes of the approach towards drought and water scarcity. Since drought is a recurring feature of UK climate (Marsh et al., 2007) and recent drought events took place between 2010-2012, 2004-2006, 2003 and 1995-1996 (Met Office, 2016, 2013, 2012), UK businesses and industries were affected in the past and this category tries to determine how they responded to these events.

A last category assessed what future challenges but also solutions trade associations identify and envisage with regard to drought and water scarcity. This future oriented question elicited any strategies, instruments or technologies to be better prepared for future drought and 
water scarcity events. To some extent this overlaps with previous categories but the questions was asked specifically at the end of the interview to allow respondents to think broadly with regard to drought and water scarcity.

In summary, these categories try to explore key aspects of how UK business and industry trade associations approach drought and water scarcity as an issue. The analysis does not claim to provide a comprehensive picture but a first explorative insight supported by examples into a neglected aspect of not only drought and water scarcity management but water resources management in general.

\section{Results and Discussion}

This section starts with a general overview based on the review of academic literature and documents. It will then present results based on the analysis of trade association documents and the three expert interviews. The section concludes with a summarising discussion of the results.

Kurland \& Zell (2010) declare a "paucity of water-related studies" in top journals in this regard. In relation to planetary boundaries and business, Whiteman et al. (2012) conclude that businesses have not addressed water scarcity despite its importance. Ya He \& Cranston (2014) demonstrate that businesses choose collaborative solutions if they recognise that poor water security is a threat to their businesses. Their example demonstrated that once interdependencies were identified by the different stakeholders and collaboration recognised, more effective water strategies and financial mechanisms were delivered that recognised the value of water to the interdependent nexus elements across different sectors (cited in Green et al., 2017). Green et al. (2017) discuss the critical role of the private sector around food, energy, water and the environment under the so-called Water-Energy-Food nexus (WEF). This 'nexus' approach highlights the interdependencies between water, energy and food. From the perspective of water, water is not seen as a sector or issue area but as a cross-cutting issue, which requires changes in governance in all relevant sectors. "This is on the basis of the argument that water governance cannot itself regulate land, agriculture or other issues in society but that water 
issues need to be taken into account in each of these governance processes" (Gupta et al., 2013). Green et al.'s (2017) study identifies 40 key questions that, if answered, help companies understand and manage their water-food-energy-environment nexus dependencies and impacts. A common issue among a number of questions was problem awareness or in the words of the authors "understanding how risks manifest around unsustainable management of food, energy, water and environmental systems is key for businesses operating under conditions of increased demand for natural resources" (Green et al., 2017). In the following, the results of the three expert interviews are described and discussed based on the categories as outlined in the Methods section.

\subsection{Role of drought and water scarcity}

The role of drought differs from sector to sector. It depends for example on whether water is used during the production process, afterwards, for cleaning purposes for instance, or both. The Horticultural Trade Association (HTA), who represents the interests of the gardening industry, sees the role of drought and water scarcity as critical. "Container grown plants have no connection to the soil and require frequent irrigation. Although modern growing media have a fairly grained structure by design, high water holding capacity etc., many of them grow in glass houses with no natural rain. In a drought most businesses would be out of business within 24 hours." (Interview HTA).

The Food and Drink Federation (FDF) represents the interests of the UK food and drink industry, the largest manufacturing sector in the country. It is a diverse sector with over 400,000 employees and around 7,000 businesses across the UK (Food and Drink Federation, 2017). The FDF believes it is important to distinguish between a genuine drought emergency and ongoing water scarcity issues in some parts of the country brought about by pressures from climate change and increasing water demand. "Normally in drought situations the Environment Agency would ask for voluntary 'hands off' reductions in abstraction first with mandatory reductions very much a last resort." (Interview FDF). Separately, there has been much discussion recently within the sector regarding the Government's proposals to move forward 
with abstraction licence reform in England and how to ensure that water for food and drink production is accorded the right priority within any new system.

The Scotch Whisky Association (SWA) represents over 90\% of the Scotch whisky industry. The industry considers itself to be in a fortunate position with regard to drought and water scarcity. "Scotland is lucky in terms of available water" (Interview SWA). 80\% of the water that is used for Scotch Whisky production is cooling water, i.e. water temperature will likely be the more limiting factor rather than water quantity. Generally speaking, the Scotch Whisky industry are very thoughtful about water, because it is one of the key ingredients or critical resources in a whisky (Interview SWA). In addition, most of the distilleries are situated in rural places, away from industrial intensive areas, therefore conflicting water pressures are less of an issue.

\subsection{Potential effects of drought and water scarcity and reflection of drought and water scarcity in strategies, policies or reports}

The potential effects can vary between short interruptions to production processes to complete disruptions of supply chains, which can stall production all together. It was mentioned above that in case of a drought many horticultural business would be out of business within 24 hours due to their reliance on irrigation water. "Landscape gardening is severely constrained in a drought event, hose pipe bans affect garden centres and this could have serious financial disadvantages for a business with a multi-billion pound turnover." (Interview HTA). However, larger nurseries may have the room and the space to provide a supply buffer, for example an on-site reservoir or a recycling scheme.

The impact for FDF businesses would be great, because "nearly all food processing businesses need a constant supply of water, 24/7." (Interview FDF) Hence, any variation or interruption of supply would be damaging for production. Therefore, within the FDF membership there has been much emphasis on the importance of water efficiency in operations and building resilience within supply chains (ibid.). In a report, Every Last Drop - Saving water along the food supply chain (Food and Drink Federation, 2011), the FDF tries to encourage companies to use water more efficiently, and gives tips how to harvest water, save costs and 
be aware of water use. It also contains a suggestion to implement an effective environmental management system (Food and Drink Federation, 2011).

The effect on Scotch Whisky production would be a slowing down of the production process according to the SWA: "Effects are in terms of temperature, or cooling water availability, which is slowing production." (Interview SWA). During a drought event in Scotland in 2008, there were some incidents where Scotch Whisky production had to be stopped in some places for short periods (Interview SWA). The SWA uses Environmental Strategy and Progress reports (Scotch Whisky Association, 2015) to highlight where water is coming from and what it is used for. Their environmental strategy also highlights issues such as climate change and sets water efficiency targets. One of the two interviewees, a representative from a whisky distillery, said that they engage actively with water issues for example through a water risk study, which assesses water in a given geographical location and includes social, regulatory and physical aspects of actual water availability, the activity of stakeholders and regulatory pressures (Interview SWA). In combination with work on climate models, assessing water resilience, this results in a Water Risk Strategy, an assessment of regulatory pressures, climate pressures and plan on how to deal with these issues.

\subsection{Relationship with regulatory bodies and water companies}

As mentioned in the introduction, industry and businesses are not part of the key stakeholders in the UK drought governance space. Nonetheless, the relationship with regulatory bodies and water companies is vital before, during and after a drought. The HTA is member of the Abstraction Reform Advisory Group, a body that was set up by the environment ministry DEFRA to carry out a reform of the abstraction licencing scheme. In addition, they are members of the Water for Food Group, a collaboration overseen by the Environment Agency that includes everyone who is related to water, food and agricultural processing. This includes for example plant and tree nurseries, the Agriculture and Horticulture Development Board (AHDB), the potato industry, chartered surveyors, irrigators and drainage boards. The group discusses and produces a range of documents at government level. In the East Anglia region, 
the HTA is also involved in the Water Resources Anglia group alongside stakeholders such as Anglia Water, the National Farmers Union and Cranfield University.

The FDF has good links with both DEFRA and the Environment Agency on water related issues (Interview FDF). It chairs the EA's sector liaison group which meets twice a year. In addition, FDF is a member of the coalition of agri food interests known as the Water for Food Group, which also includes the HTA and the National Farmers Union for example.

The key relationships the SWA holds are with DEFRA, Scottish Water and the Scottish Environment Protection Agency (SEPA). The relationship with water companies is on an ad hoc basis because many distillers have their own private water supply. "We have a very good and proactive relationship with SEPA" (Interview SWA), which even sees the Scotch whisky industry as a best practice example on how SEPA would like to work with other business sectors in Scotland. SEPA's One Planet Prosperity regulatory approach uses a sectoral approach. "Sector plans will focus on practical ways of delivering environmental, social and economic outcomes. They will specify existing levels of compliance, the market context for that sector and the key issues faced by the sector and SEPA" (SEPA, 2016). The distillery representative mentioned the membership of the Beverage Industry Environment Round table (BIER), where water is one of the topics they discuss.

\subsection{Experience with past drought events and changes in the approach towards drought and water scarcity}

There have been recent drought events in the UK, for example 2010-2012 (Met Office, 2013), 2004-2006 (Met Office, 2016) or 2003 (Met Office, 2012). The HTA attended the drought summit that was convened by DEFRA after the 2010-2012 drought. The interviewee himself remembered the 1976 drought. "The last drought event immediately galvanised the mind and we went to several water companies to ask them to introduce a traffic light scheme [indicating the severeness of drought using green, yellow and red]. The water companies' reaction was that they agreed to look at it." (Interview HTA) Another issue that was picked up after the last drought event was to look at more drought-hardy plants such as cacti or succulents, however 
they are not as colourful as other ornamental plants. "The horticultural market is a leisure market, not a food market" (Interview HTA).

The FDF also mentions the 2010-2012 drought and the good communication it was able to establish with its members as a result of the information provided by the Environment Agency.

As mentioned before the effect of drought or water scarcity on Scotch Whisky production is minimal as opposed to other industries. The SWA recalls a few days without or reduced production for a handful of locations over the last decade. The 2012 drought caused furthermore short periods of low flows. (Interview SWA) As a response we find the above mentioned Water Risk study by the distillery as well as the updated Environmental Strategy and Progress reports by the SWA and its collaboration with SEPA.

\subsection{Future challenges and solutions}

For the HTA, one of the key strategies is to think about water saving processes: "There are some very sophisticated technologies, for example looking at soil moisture content, or telling the volumetric water content of a media and if it goes down a certain level, irrigation is triggered." (Interview HTA). Other solutions include the use of rain gauges that stop irrigation if it rains, the increased use of smart metering, the use of more recycled water: "We could use more grey water." (ibid.). In a wider perspective, the HTA mentions the use of canals to move water across areas and to hold rainfall back instead of letting it run off into the sea. Another option would be aggregate abstraction licences in an area with many plant nurseries and take the water from where the most is available, linking nurseries by pipes.

For the FDF one of the major future challenges will be how to find ways to increase national food production to meet national priorities around economic growth including exports and food security given the pressures on water availability in some parts of the country (Interview FDF). In a separate report by DEFRA and the EA (2016), a beverage company is showcased. Here, a review on water usage has prompted changes in run time on pumps and 
other equipment. The manufacturing site has become more self-sufficient also due to its own on-site water source.

The strategy for the SWA is to use bigger companies to take leadership and share knowledge, technology and experience. “The big companies' strategy gives us a framework to have these discussions and if there are any lessons to learn in order to be ahead of the game." (Interview SWA). From a distiller's perspective, they are fortunate to be in a resilient water catchment and that they are the only ones there. "We do rely on the regulatory framework to keep it that way. (...) If land management changes, planned forestry or less planned development that could change water availability." (Interview SWA)

\subsection{Other industries and large abstractors}

The above detailed analysis focussed on three sectors and the objective was to provide an exploratory insight into drought and water scarcity and its management among large business and industrial abstractors in the UK. There are of course many more water intensive UK industries such as the cement industry, chemical industries, paper industries, mineral industries, hydropower, the energy sector, especially thermal power plants or the glass industry. Some of them have been approached for interviews or statements. As mentioned before, all of them were contacted but they either declined, follow-ups were not answered or they did not respond at all to requests. DEFRA has also produced a study on the impacts of drought in England on various sectors in 2013 (DEFRA, 2013). The following therefore presents an overview of documents that are publicly available.

The UK's paper-based industries are unified under the umbrella of the Confederation of Paper Industries (CPI). They represent 70 Companies, among them makers of soft tissue papers, paper and board manufacturers, corrugated packaging producers and many more. Their aim is to promote paper as a sustainable and renewable material and to reach the best regulatory and legislative practice. The industry has $£ 6.5 \mathrm{bn}$ annual turnover capital and more than 100,000 employees (CPI, 2017a). In its annual review the CPI (2017b) writes: "Turning closer to home, issues around water scarcity and indeed water abundance abound." The annual review also highlights the importance of water scarcity and the idea/need of adaptation to the challenges of 
climate change in general. The paper and pulp sector has its own guidance to prepare for climate change supported by the Environment Agency (2013). This action plan contains a questionnaire to assess businesses, recommendations for creating a risk map and how to explore critical thresholds of water usage.

According to the British Hydropower Association, hydropower in the UK generates almost 6000 GWh electricity per year (British Hydropower Association, 2017). Hydropower generation relies to one hundred percent on water availability, or in other words, drought and water scarcity could bring hydropower generation to a complete halt.

The Construction Products Association states in a report that "Whilst concern is usually on water scarcity, the increasingly volatile weather patterns in the UK are causing regular, often severe, flooding (five of the wettest years on record have been since 2000); for manufacturers both scarcity and flooding can pose a business risk." (Thornback et al., 2015) The report also highlights the different uses of water in various construction product manufacturing processes such as pre-cast concrete, plastics, wood panels, ceramics, glass, quarries and steel (Thornback et al., 2015). Citing a member survey, they say that manufacturers are becoming increasingly aware of water related issues. "Business risks can manifest in two main ways - either through restriction of the quantity of water available (whether physical or regulatory related) or though declining water quality" (Thornback et al., 2015, p. 12).

\subsection{Summary}

There is no one size fits all solution how businesses and industry in the UK should deal with drought and water scarcity. Responses, strategies and measures depend on business and industry size, geographical location, the interconnectedness of the supply chain, government policies and what water is used for predominantly - for the product or service itself, as coolant or for cleaning. All interviewed and analysed sectors have had experiences with droughts and water scarcity in the recent past and all of them are aware that future drought and water scarcity events can cause disruption to businesses and industries. Noteworthy is the position of the SWA, who although water scarcity and droughts are not an imminent threat to them takes care of water issues proactively because it is one of the key ingredients to their product. What unites 
all three interviewed sectors is the importance of relationships with other stakeholders, predominantly neighbouring sectors, regulatory bodies and water companies. This is for example obvious in the case of the Food and Drink sector. Many ingredients are sourced from the agricultural sector and it is therefore vital to collaborate with the National Farmers Union for example. The Water for Food group overseen by the Environment Agency is another positive example that fosters collaboration among the different stakeholders.

The HTA even proactively engaged with water companies after the last drought in order to be better prepared for future droughts. In the East Anglia region the HTA approached water companies, Essex and Suffolk Water and Affinity Water, to introduce a traffic light scheme, so that people and businesses can better prepare for a drought event (Interview HTA). Another approach is to focus on technological solutions, either, with reference to the sectors covered in this study, at distillery or plant nursery level. Water recycling and the use of recycled water, drought-hardy plants, on-site reservoirs, canals to distribute water among nurseries in vicinity to each other or soil moisture measurement technologies that only trigger irrigation when really necessary are measures to adapt to varying water availability but are also measures to increase water efficiency.

This exploratory study gave a snapshot of how different business and industry sectors in the UK approach drought and water scarcity and the scope of the study is therefore limited. As mentioned in the method and data section many more industries were contacted but either declined and interview or did not respond at all. Those who declined mentioned that the issue is not relevant for their membership or not discussed by their membership. This could be addressed by raising awareness among industries for example by linking the issue to other relevant water related issues such as flooding. Water scarcity often is a consequence of flooding. Since flooding in general is usually more appealing to stakeholders this could be an entry point to widen the debate with drought and water scarcity issues. Nonetheless, the selected sectors use water in their operations and production processes in different ways and do exemplify some of the major challenges that are incurred by drought and water scarcity. 
It is important to emphasise that drought and water scarcity are only two of many other possible extreme weather events that could affect businesses and industry. Flooding, heat waves, land slides, bush and forest fires or hurricanes can disrupt supply chains and production processes (Linnenluecke et al., 2012).

\section{Conclusions}

The aim of this research was to explore how different business and industry sectors in the UK deal with drought and water scarcity. Not only in the light of climatic changes do drought and water scarcity have ecological consequences and put risk on domestic users of water but they also hold severe implications for businesses, industries and their supply chains ranging from slowed down production to the interruption of production processes over long time periods. The role of drought and water scarcity and the extent to how each sector could be affected unsurprisingly varies across the different sectors. Nonetheless, businesses and industries in the UK are aware of the potential effects of drought and water scarcity either because they experienced drought events before or they are forward thinking in their approach to water resources. The solutions to future challenges of drought and water scarcity are tackled through technological solutions and cooperation with other sectors and regulatory bodies. Especially the latter should be fostered and institutionalised as businesses and industries currently do not belong to the key stakeholders in the UK drought governance space. For example, the Water Resources in the South East Group (WRSE) and Water Resources East Group in Anglia are two organisations in the UK that foster the collaboration between water companies, regulators and other stakeholders in the respective regions. They could serve as a model for other regions as well.

\section{References}

Bates, B.C., Kundzewicz, Z.W., Wu, S., Palutikof, J.P., 2008. Climate Change and Water. Technical Paper of the Intergovernmental Panel on Climate Change. IPCC, Geneva. BBC News, 2016. Ginger nut biscuit “crisis over.” BBC News. 
Benton, T., Gallani, B., Jones, C., Lewis, K., Tiffin, R., Donohoe, T., 2012. Severe weather and UK food chain resilience. Detailed Appendix to Synthesis Report. Food Research Partnership: Resilience Of The UK Food System Subgroup, Swindon.

British Hydropower Association, 2017. Hydro in the UK [WWW Document]. URL http://www.british-hydro.org/hydro_in_the_uk (accessed 6.13.17).

Brown, K.P., Hess, D.J., 2017. The politics of water conservation: identifying and overcoming barriers to successful policies. Water Policy 19, 304-321. https://doi.org/10.2166/wp.2016.089

Bryman, A., 2012. Social research methods. Oxford University Press, New York.

Committee on Climate Change Risk Assessment, 2016. UK Climate Change Risk Assessment 2017. Synthesis Report: priorities for the next five years. London.

CPI, 2017a. Who we are [WWW Document]. URL http://www.paper.org.uk/aboutcpi/pages/who_we_are.html (accessed 5.26.17).

CPI, 2017b. Pride in Paper. Review 2016/17. Confederation of Paper Industries, Swindon.

DEFRA, 2013. The impacts of drought in England. R\&D Technical Report WT0987/TR. Department for Environment, Food and Rural Affairs, London.

Department of Environment, Food and Rural Affairs, Environment Agency, 2016. Creating a better place. Our ambition to 2020. Department for Environment, Food and Rural Affairs; Environment Agency, London, Bristol.

Environment Agency, 2013. Preparing a Climate Change Action Plan: Paper \& Pulp Sector Guidance. Environment Agency.

Food and Drink Federation, 2017. FDF - Stats at a Glance.

Food and Drink Federation, 2011. Every Last Drop - Saving water along the food supply chain. Food and Drink Federation.

Fowler, F.J., Mangione, T.W., 1990. Standardized Survey Interviewing. Minimizing Interviewer-Related Error. Sage, Newbury Park.

Gasbarro, F., Rizzi, F., Frey, M., 2016. Adaptation Measures of Energy and Utility Companies to Cope with Water Scarcity Induced by Climate Change. Business Strategy \& the Environment (John Wiley \& Sons, Inc) 25, 54-72. https://doi.org/10.1002/bse.1857

Green, J.M.H., Cranston, G.R., Sutherland, W.J., Tranter, H.R., Bell, S.J., Benton, T.G., Blixt, E., Bowe, C., Broadley, S., Brown, A., Brown, C., Burns, N., Butler, D., Collins, H., Crowley, H., DeKoszmovszky, J., Firbank, L.G., Fulford, B., Gardner, T.A., Hails, R.S., Halvorson, S., Jack, M., Kerrison, B., Koh, L.S.C., Lang, S.C., McKenzie, E.J., Monsivais, P., O’Riordan, T., Osborn, J., Oswald, S., Price Thomas, E., Raffaelli, D., Reyers, B., Srai, J.S., Strassburg, B.B.N., Webster, D., Welters, R., Whiteman, G., Wilsdon, J., Vira, B., 2017. Research priorities for managing the impacts and dependencies of business upon food, energy, water and the environment. Sustainability Science 12, 319-331. https://doi.org/10.1007/s11625-016-0402-4

Gupta, J., Pahl-Wostl, C., Zondervan, R., 2013. 'Glocal' water governance: a multi-level challenge in the anthropocene. Current Opinion in Environmental Sustainability 5, 573-580. https://doi.org/10.1016/j.cosust.2013.09.003 
Hoolohan, C., Browne, A.L., 2016. Reframing Water Efficiency: Determining Collective Approaches to Change Water Use in the Home. British Journal of Environment \& Climate Change 6, 179-191.

Jenkins, K., 2013. Indirect economic losses of drought under future projections of climate change: a case study for Spain. Nat Hazards 69, 1967-1986. https://doi.org/10.1007/s11069-013-0788-6

Jiménez Cisneros, B.E., Oki, T., Arnell, N.W., Benito, G., Cogley, J.G., Döll, P., Jiang, T., Mwakalila, S.S., 2014. Freshwater resources, in: Field, C.B., Barros, V.R., Dokken, D.J., Mach, K.J., Mastrandrea, M.D., Bilir, T.E., Chatterjee, M., Ebi, K.L., Estrada, Y.O., Genova, R.C., Girma, B., Kissel, E.S., Levy, A.N., MacCracken, S., Mastrandrea, P.R., White, L.L. (Eds.), Climate Change 2014: Impacts, Adaptation, and Vulnerability. Part A: Global and Sectoral Aspects. Contribution of Working Group II to the Fifth Assessment Report of the Intergovernmental Panel of Climate Change. Cambridge University Press, Cambridge, United Kingdom and New York, NY, USA, pp. 229-269.

Kurland, N.B., Zell, D., 2010. Water and Business: A Taxonomy and Review of the Research. Organization \& Environment 23, 316-353. https://doi.org/10.1177/1086026610382627

Lange, B., Cook, C., 2015. Mapping a Developing Governance Space: Managing Drought in the UK. Current Legal Problems 68, 1-38. https://doi.org/10.1093/clp/cuv014

Linnenluecke, M.K., Griffiths, A., Winn, M., 2012. Extreme Weather Events and the Critical Importance of Anticipatory Adaptation and Organizational Resilience in Responding to Impacts. Business Strategy \& the Environment (John Wiley \& Sons, Inc) 21, 17-32. https://doi.org/10.1002/bse.708

Lloyd-Hughes, B., 2013. The impracticality of a universal drought definition. Theoretical and Applied Climatology 117, 607-611. https://doi.org/10.1007/s00704-013-1025-7

Marsh, T., Cole, G., Wilby, R., 2007. Major droughts in England and Wales, 1800-2006. Weather 62, 87-93. https://doi.org/10.1002/wea.67

Martin-Ortega, J., González-Eguino, M., Markandya, A., 2012. The costs of drought: the 2007/2008 case of Barcelona. Water Policy 14, 539-560. https://doi.org/10.2166/wp.2011.121

Mayring, P., 2008. Qualitative Inhaltsanalyse. Grundlagen und Techniken., 10th ed. Beltz, Weinheim.

Merton, R.K., Kendall, P.L., 1946. The focussed interview. American Journal of Sociology 51, 541-557.

Met Office, 2016. Dry spell 2004/6 [WWW Document]. Met Office. URL http://www.metoffice.gov.uk/climate/uk/interesting/2004_2005dryspell (accessed 7.28.17).

Met Office, 2013. England and Wales drought 2010 to 2012 [WWW Document]. Met Office. URL http://www.metoffice.gov.uk/climate/uk/interesting/2012-drought (accessed 7.28.17).

Met Office, 2012. Dry weather during 2003 [WWW Document]. Met Office. URL http://www.metoffice.gov.uk/climate/uk/interesting/2003dryspell.html (accessed 7.28.17). 
Morren, G.E.B., 1980. The rural ecology of the British drought of 1975-1976. Hum Ecol 8, 33-63. https://doi.org/10.1007/BF01531467

Nauges, C., Wheeler, S.A., 2017. The Complex Relationship Between Households' Climate Change Concerns and Their Water and Energy Mitigation Behaviour. Ecological Economics 141, 87-94. https://doi.org/10.1016/j.ecolecon.2017.05.026

Rey, D., Holman, I.P., Daccache, A., Morris, J., Weatherhead, E.K., Knox, J.W., 2016. Modelling and mapping the economic value of supplemental irrigation in a humid climate. Agricultural Water Management 173, 13-22. https://doi.org/10.1016/j.agwat.2016.04.017

Scotch Whisky Association, 2015. Scotch Whisky Industry. Environmental Strategy Report 2015. Edinburgh.

SEPA, 2016. One Planet Prosperity - Our Regulatory Strategy. (Scottish Environment Protection Agency).

Taylor, V., Chappells, H., Medd, W., Trentmann, F., 2009. Drought is normal: the sociotechnical evolution of drought and water demand in England and Wales, 1893-2006. Journal of Historical Geography 35, 568-591. https://doi.org/10.1016/j.jhg.2008.09.004

Thomas, W.T.B., 2015. Drought-resistant cereals: impact on water sustainability and nutritional quality. Proceedings of the Nutrition Society 74, 191-197. https://doi.org/10.1017/S0029665115000026

Thornback, J., Snowdon, C., Anderson, J., Foster, C., 2015. Water Efficiency. The contribution of construction products. 2015. Construction Products Association, London.

Van Loon, A.F., Van Lanen, H. a. J., 2013. Making the distinction between water scarcity and drought using an observation-modeling framework. Water Resour. Res. 49, 1483-1502. https://doi.org/10.1002/wrcr.20147

Weinhofer, G., Busch, T., 2013. Corporate Strategies for Managing Climate Risks. Business Strategy \& the Environment (John Wiley \& Sons, Inc) 22, 121-144. https://doi.org/10.1002/bse.1744

Whiteman Gail, Walker Brian, Perego Paolo, 2012. Planetary Boundaries: Ecological Foundations for Corporate Sustainability. Journal of Management Studies 50, 307-336. https://doi.org/10.1111/j.1467-6486.2012.01073.x

Wilhite, D.A., Sivakumar, M.V.K., Pulwarty, R., 2014. Managing drought risk in a changing climate: The role of national drought policy. Weather and Climate Extremes, High Level Meeting on National Drought Policy 3, 4-13. https://doi.org/10.1016/j.wace.2014.01.002

Winn, M., Kirchgeorg, M., Griffiths, A., Linnenluecke, M.K., Günther, E., 2011. Impacts from climate change on organizations: a conceptual foundation. Business Strategy \& the Environment (John Wiley \& Sons, Inc) 20, 157-173. https://doi.org/10.1002/bse.679

Witzel, A., 2000. The Problem-centered Interview. Forum Qualitative Social Research 1, Art. 22. 
Ya He, J., Cranston, G.R., 2014. The Cambridge Natural Capital Leadership Platform. Sink or Swim: A multi-sector collaboration on water asset investment. Institute for Sustainability Leadership, Cambridge, UK. 